\title{
Increase of Dialysate Dopamine in the Bed Nucleus of Stria Terminalis by Clozapine and Related Neuroleptics
}

\author{
Ezio Carboni, Ph.D., Maria T.P. Rolando, Ph.D., Alessandra Silvagni, Ph.D., \\ and Gaetano Di Chiara, M.D.
}

\begin{abstract}
Neuroleptics are known to stimulate dopamine release in neostriatal terminal areas. In the present study, we have investigated by brain microdialysis in freely moving rats the effect of typical and atypical neuroleptics on dopamine transmission in the bed nucleus of stria terminalis, a dopamine terminal area belonging to the limbic system and recently assigned the so-called extended amygdala. Mean basal dialysate dopamine values were $14.3 \mathrm{f}$ moles $/ 20 \mu \mathrm{l}$ sample. Dopamine output in dialysates was increased dosedependently by clozapine (max $+158 \%, 298 \%$, and $461 \%$ of basal at 5, 10, and $20 \mathrm{mg} / \mathrm{kg} I P$, respectively), risperidone $(\mathrm{max}+115 \%$ and $221 \%$ of basal at 1 and $3 \mathrm{mg} / \mathrm{kg} \mathrm{IP}$, respectively), olanzapine (max $+138 \%$ and $235 \%$ of basal at 3 and $6 \mathrm{mg} / \mathrm{kg} I P$, respectively), BIMG 80 (max $+64 \%$ and $164 \%$ of basal at 3 and $5 \mathrm{mg} / \mathrm{kg}$ IP, respectively), amperozide (max $+110 \%$ and $194 \%$ of basal at 3 and 6 $\mathrm{mg} / \mathrm{kg} I P$, respectively). The selective dopamine $\mathrm{D}_{4}$ antagonist $L-745,870$ increased dialysate dopamine but at rather high doses and not as effectively as clozapine (max + $32 \%, 89 \%$, and $130 \%$ of basal at $2.7,5.4$, and $10.8 \mathrm{mg} / \mathrm{kg}$
\end{abstract}

$I P$, respectively). The typical neuroleptic haloperidol ( 0.1 and $0.5 \mathrm{mg} / \mathrm{kg} \mathrm{SC}$ ) and the selective $\mathrm{D}_{2}$ antagonist raclopride $(0.14,0.56$, and $2.1 \mathrm{mg} / \mathrm{kg} \mathrm{SC})$, the serotonergic $5-\mathrm{HT}_{2}$ antagonist ritanserin ( 0.5 and $\left.1.5 \mathrm{mg} / \mathrm{kg} \mathrm{IP}\right)$, and the adrenergic $\alpha_{1}$ antagonist prazosin (0.91 and $2.73 \mathrm{mg} / \mathrm{kg} \mathrm{IP}$ ) did not affect dialysate dopamine in the bed nucleus of stria terminalis. Saline $(1 \mathrm{ml} / \mathrm{kg} S C$ or $3 \mathrm{ml} / \mathrm{kg} \mathrm{IP})$ did not modify dialysate dopamine. Therefore, atypical neuroleptics share the ability of stimulating dopamine transmission in the bed nucleus of stria terminalis, but this property is not mimicked by any of the drug tested that selectively act on individual receptors among those that are affected by atypical neuroleptics. These observations raise the possibility that the property of increasing dopamine transmission in the bed nucleus of stria terminalis is the result of combined blockade of dopamine, serotonin, and noradrenaline receptors and that might be predictive of an atypical neuroleptic profile. [Neuropsychopharmacology 22:140-147, 2000] (C) 1999 American College of Neuropsychopharmacology. Published by Elsevier Science Inc.
KEY WORDS: Dopamine; Bed nucleus of stria terminalis (BNST); Clozapine; Microdialysis; Antipsychotics

Neuroleptics are a class of antipsychotics having in common the property of blocking the dopamine (DA) receptors of the D2 family. Among neuroleptics, clozapine

From the Department of Toxicology, and C.N.R. Center for Neuropharmacology, University of Cagliari, Cagliari, Italy.

Address correspondence to: Ezio Carboni Ph.D., Department of Toxicology, Viale Diaz 182, 09126 Cagliari, Italy.

Received March 12, 1999; revised June 28, 1999; accepted July 12, 1999. has some peculiar properties as compared with typical neuroleptics; namely, a reduced tendency to elicit extrapyramidal side effects and a therapeutic efficacy on negative symptoms of schizophrenia and schizophrenic patients resistant to typical neuroleptics (Arnt and Skarsfeldt 1998; Brunello et al. 1995). These properties of clozapine have been attributed to a distinct but relatively low affinity for $D_{2}$ receptors (Coward 1992; Leysen et al. 1993) and to a high affinity for 5- $\mathrm{HT}_{2}$ (Meltzer et al. 1989) and other non-DA receptors (e.g., $\alpha_{1}$ ) (Cohen and Lipinski 1986) as compared with typical neuroleptics. More re- 
cently clozapine has been shown to have higher affinities for $D_{4}$ as compared with $D_{2}$ receptors (Van Tol et al. 1991). On the basis of the above observations and in the attempt to mimic the therapeutic profile of clozapine, a number of neuroleptics that share the $\mathrm{D}_{2} / \mathrm{D}_{4}$ as well as the $5-\mathrm{HT}_{2 \mathrm{~A}}$ and $\alpha_{1}$ blocking properties of clozapine have been developed (Arnt and Skarsfeldt 1998). A property common to classic and novel neuroleptics including clozapine is that of stimulating in vivo DA release in terminal DA areas (Imperato and Di Chiara 1985; Imperato and Angelucci 1989; Meltzer et al. 1989; Moghaddam and Bunney 1990). This property is commonly explained as a negative feedback secondary to blockade of DA receptors in terminal DA areas. In the case of clozapine and atypical neuroleptics, non-DA receptor mediated mechanisms (5- $\mathrm{HT}_{2}, \alpha_{1}$ etc.) might contribute to the stimulation of DA release in specific brain areas (e.g., prefrontal cortex) (Nomikos et al. 1994; Moghaddam and Bunney 1990; Andersson et al. 1995).

Recently, a number of areas traditionally included in the limbic system, such as the central amygdala, bed nucleus of stria terminalis (BNST), sublenticular substantia innominata, and other minor areas intercalated among the above ones, have been reassembled into an extensive and complex system termed "the extended amygdala" (Heimer et al. 1993). This system is thought to be interconnected with the striatum by way of the nucleus accumbens shell that is, accordingly, viewed as a transition area between the striato-pallidal system and the extended amygdala (Heimer et al. 1993). It is notable in this respect that, on the basis of studies on the effect of typical and atypical neuroleptics on the expression of the early gene c-fos, the nucleus accumbens shell has been indicated as a common substrate of the therapeutic action of neuroleptics on the positive symptoms of schizophrenia (Robertson and Fibiger 1992; Deutch and Duman 1996). Most of the areas which constitute the extended amygdala receive dense DA projections from the ventral tegmental area (VTA) (Heimer et al. 1993; Tohyama and Taketsuji 1998). Based on these premises, we investigated the effect of neuroleptics both typical and atypical on the release of DA in a major area of the extended amygdala, such as the BNST.

\section{MATERIALS AND METHODS}

\section{Animals}

Male Sprague-Dawley rats (Charles River, Calco, Italy) weighing 230 to $250 \mathrm{~g}$ were housed under standard conditions of temperature and humidity under an artificial light (light from 8 A.M. to 8 P.M.).

\section{Probe Preparation}

Concentric dialysis probes were prepared with a 7-mm piece of AN 69 (sodium methallyl sulfate copolymer) dialysis fiber (310 $\mu$ m o.d. $220 \mu \mathrm{m}$ i.d. Hospal, Dasco, Italy), sealed at one end with a drop of epoxy; the sealed end was then sharpened with an abrasive disk. One of two 5-cm long pieces of fused silica (Composite Metal Services, UK) was sharpened to have the opening on a side and then was introduced in a $20-\mathrm{mm}$ piece of stainless steel (obtained from a 24-gauge syringe needle) having the sharpened end coming out from the sharpened end of the needle for $9 \mathrm{~mm}$. The second 5- $\mathrm{cm}$ long piece of silica was introduced from a side hole (made at $5 \mathrm{~mm}$ from the sharpened end of the needle) until it came out $7 \mathrm{~mm}$ from the sharpened end of the needle. The two silica tubings were sealed to the needle with epoxy and were introduced in the dialysis fiber, taking care to have the inlet reaching the lower end of the dialyzing portion $(2.0 \mathrm{~mm})$ of the fiber. The dialysis fiber was covered with thin layer of epoxy glue, except for the dialyzing portion, and, at the same time, the open end was sealed to the silica tubing. The outlet coming out from the side hole of the $20-\mathrm{mm}$ stainless steel tubing was introduced in a $1.7-\mathrm{mm}$ stainless steel tubing. The two stainless steel tubings were introduced in a piece of 200- $\mu \mathrm{l} \mathrm{micropipette} \mathrm{tip} \mathrm{7-mm} \mathrm{long} \mathrm{and} \mathrm{glued} \mathrm{to}$ it. Following its assembly, the probe was dried for $24 \mathrm{~h}$.

\section{Surgery and Experiments}

Rats were anesthetized with ketamine (Ketalar ${ }^{\circledR}$, ParkDavis, Milan, Italy) and placed in a stereotaxic apparatus. The skull was exposed, and a small hole was drilled on one side. The probe was implanted vertically in the BNST (anterior: - 0.5; lateral: 1.1; vertical: 8.1, from bregma), according to the atlas of Paxinos and Watson (1982), and then fixed on the skull with dental cement. Rats were housed in a transparent plastic (Plexiglas) hemisphere, closed with a top hemisphere, with food and water available.

Experiments were performed on freely moving rats $24 \mathrm{~h}$ after probe implant. Ringer's solution (147 mM, $\mathrm{NaCl} ; 2.2 \mathrm{mM} \mathrm{CaCl}_{2} ; 4 \mathrm{mM} \mathrm{KCl}$ ) was pumped through the dialysis probe at constant rate of $1 \mu \mathrm{l} / \mathrm{min}$. Samples were taken every $20 \mathrm{~min}$ and analyzed.

Figure 1 shows the position of the dialyzing part of the fiber in a schematic representation of a frontal (top) and horizontal (bottom) section of the rat brain at the level of BNST (A $=-0.3 \mathrm{~mm}$, and $\mathrm{V}=6.6$ from bregma, respectively) redrawn from Paxinos and Watson (1982). All animal experimentation was conducted in accordance with the guidelines for care and use of experimental animals of the European Economic Community (86/809; DL 27.01.92 No. 116).

\section{Analytical Procedure}

Dialysate samples $(20 \mu \mathrm{l})$, were injected without any purification into a high-performance liquid chromatog- 

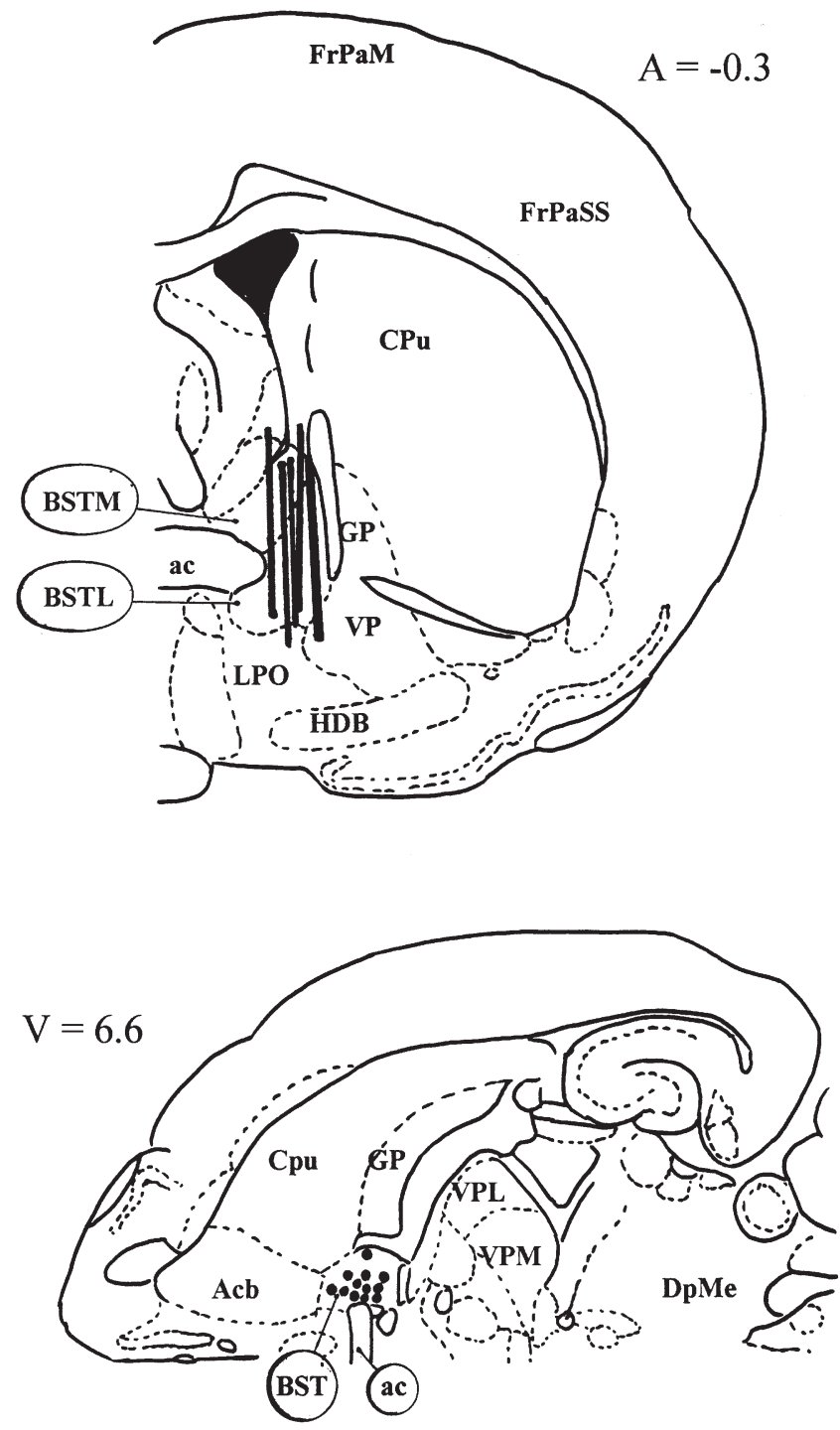

Figure 1. Schematic representation of a frontal section (top) and horizontal section (bottom) of rat brain at A $-0.3 \mathrm{~mm}$ and V 6.6 from bregma, respectively, according to the atlas of Paxinos and Watson (1982). In the frontal section, the position of the dialyzing part of the fiber is illustrated approximately as observed in one frontal section at the level of the central part of the BNST. Abbreviations: ac, anterior commissure; Acb, accumbens nucleus; BSTL, bed nucleus stria terminalis lateralis; BSTM bed nucleus stria terminalis medialis; $\mathrm{Cpu}$, caudate putamen; $\mathrm{DpMe}$, deep mesencefalic nucleus; FrPaM, frontoparietal cortex, motor area; FrPaSS, frontoparietal area, somatosensory area; GP globus pallidus; HDB nucleus horizontal limb diagonal band; LPO, lateral preoptic area; VP, ventral pallidum; VPL ventroposterior thalamic nucleus lateralis; VPM ventroposterior thalamic nucleus medialis.

raphy (HPLC) apparatus equipped with reverse-phase column (LC -18 DB, Supelco) and a coulometric detector (ESA Coulochem II, Bedford, MA) to quantitate DA. The first electrode was set at $+130 \mathrm{mV}$ and the second electrode at $-125 \mathrm{mV}$ ). The composition of the mobile phase was: $50 \mathrm{mM} \mathrm{Na} \mathrm{H} \mathrm{PO}_{4} / 5 \mathrm{mM} \mathrm{Na}_{2} \mathrm{HPO}_{4}, 0.1 \mathrm{mM}$ $\mathrm{Na}_{2}$ EDTA, $0.5 \mathrm{mM}$ octyl sodium sulfate, $15 \%$ (vol./vol.) methanol, $\mathrm{pH}$ 5.5. The mobil phase was pumped with an LKB 2150 pump at a flow rate of $1.0 \mathrm{ml} / \mathrm{min}$. The sensitivity of the assay allowed the detection of $5 \mathrm{f}$ moles of DA.

\section{Histology}

At the end of the experiment, rats were anesthetized with chloral hydrate $(0.32 \mathrm{~g} / \mathrm{kg}$ IP) and then transcardially perfused with $100 \mathrm{ml}$ of saline $(0.9 \% \mathrm{NaCl})$ and $100 \mathrm{ml}$ of formaldehyde $(10 \%)$. The probes were removed, and brains were cut on a vibratome in serial coronal slices oriented according the atlas of Paxinos and Watson (1982) to locate the position of fiber.

\section{Drugs}

BIMG 80, risperidone, clozapine, amperozide, and olanzapine were kindly provided by Dr. Franco Borsini, Boheringer Italy); L-745,870 $\mathrm{HCl}$ was a gift from Merck, Sharp, and Dohme, UK; other drugs were obtained from commercial sources: haloperidol (Serenase ${ }^{\circledR}$, from Lusofarmaco Italy), prazosin $\mathrm{HCl}$, ritanserin, and raclopride tartrate from RBI-Sigma, Italy. The doses used are expressed as free base.

\section{Statistics}

Statistical analysis was carried out by Statistica (Statsoft, USA). Two-way analysis of variance (ANOVA) for repeated measures was applied to the data obtained from the serial assays of DA after each treatment. Results from treatments showing significant over-all changes were subjected to post hoc Tukey test with significance for $p<.05$. Basal values were the means of three consecutive samples differing less than $10 \%$.

\section{RESULTS}

Basal values of DA in the BNST were $14.3 \pm 1.3 \mathrm{f}$ moles / $20 \mu$ sample (mean $\pm \mathrm{SE}$ ). As shown in Figure 1, the probes were located in the lateral part of the BNST.

A significant increase of dialysate DA was elicited by various atypical and novel neuroleptics, such as clozapine (Figure 2$)$ at doses of $5.0(\max +158 \%), 10(\max +$ $298 \%$ ), and $20 \mathrm{mg} / \mathrm{kg} \mathrm{IP}$ ( $\max +461 \%$ ); risperidone (Leysen et al. 1994) (Figure 3) at doses of 1.0 (max + $115 \%$ ) and $3.0 \mathrm{mg} / \mathrm{kg}$ IP ( $\max +221 \%$ ); olanzapine (Beasley et al. 1996) (Figure 4) at doses of $3.0(\max +$ $138 \%$ ) and $6.0 \mathrm{mg} / \mathrm{kg}$ IP ( $\max +235 \%)$; BIMG 80 (Volontè et al. 1997) (Figure 5) at doses of $3.0(\max +64 \%)$ 


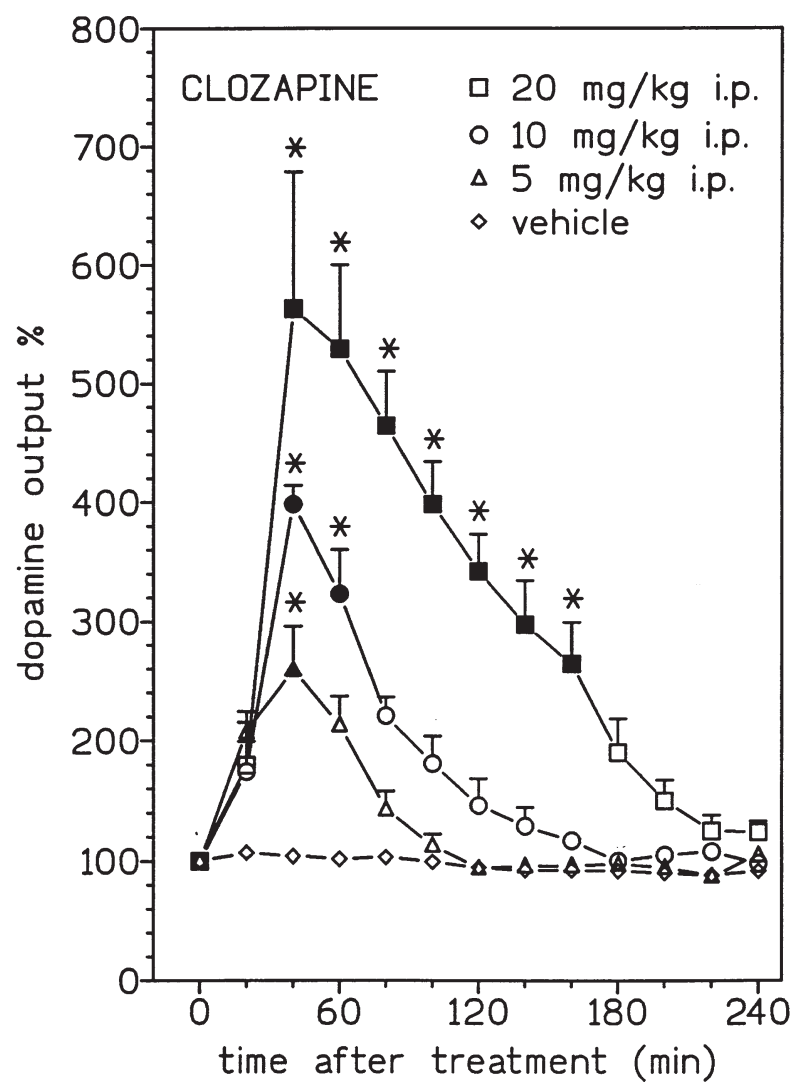

Figure 2. Effect of clozapine at three doses $(20,10$, and $5 \mathrm{mg} / \mathrm{kg}$ $\mathrm{IP}$ ) on the concentration of dopamine (DA) in dialysate obtained by in vivo microdialysis from the bed nucleus of stria terminalis (BNST). Each point is the mean \pm SEM of at least four determinations. Filled symbols: $p<.05$ from basal values concentration; * $p<.05$ from the correspondent time point of vehicle group.

and $5.0 \mathrm{mg} / \mathrm{kg} \mathrm{IP}(\max +164 \%)$; amperozide (Haskins et al. 1987) (Figure 6) at doses of $3.0(\max 110 \%)$ and 6.0 $\mathrm{mg} / \mathrm{kg} \mathrm{IP}(\max +194 \%) ; \mathrm{L}-745,870$, (Bristow et al. 1997) (Figure 7) a $\mathrm{D}_{4}$ antagonist, at doses of $5.4(\max +89 \%)$ and $10.8 \mathrm{mg} / \mathrm{kg} \mathrm{IP}(+130 \%)$. Two-way ANOVA of the results obtained by the different doses of neuroleptics showed a significant effect of dose and a significant dose $\times$ time interaction for clozapine (main effect: $\mathrm{F}$ $3,13=27.8, p<.001$; interaction: F 27,117 = 9.88, $p<$ .001 ); risperidone (main effect: F 2,9 $=22.25, p<.001$; interaction: F $14,63=2.85, p<.005$ ); olanzapine (main effect: F 2,9 = 35.1, $p<.001$; interaction: F 18,81 = 5.7, $p<$ .001); BIMG 80 (main effect: F 2,10 = 29.1, $p<.001$; interaction: $\mathrm{F} 16,80=8,7, p<.001$ ); amperozide (main ef-

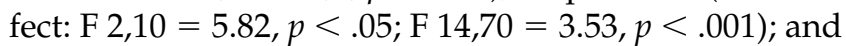
L-745,870 (main effect: F 3,13 $=67.66, p<.001$; interaction: $\mathrm{F} 21,91=10.74, p<.001$ ).

A classic neuroleptic, such as haloperidol (Figure 8) (0.1 and $0.5 \mathrm{mg} / \mathrm{kg} \mathrm{SC})$, and a specific and effective $\mathrm{D}_{2^{-}}$ antagonist, such as raclopride (Hall et al. 1988) (0.14, 0.56 , and $2.1 \mathrm{mg} / \mathrm{kg} \mathrm{SC}$ ) (Figure 9), failed to elicit significant change in dialysate DA in the BNST. Also devoid of

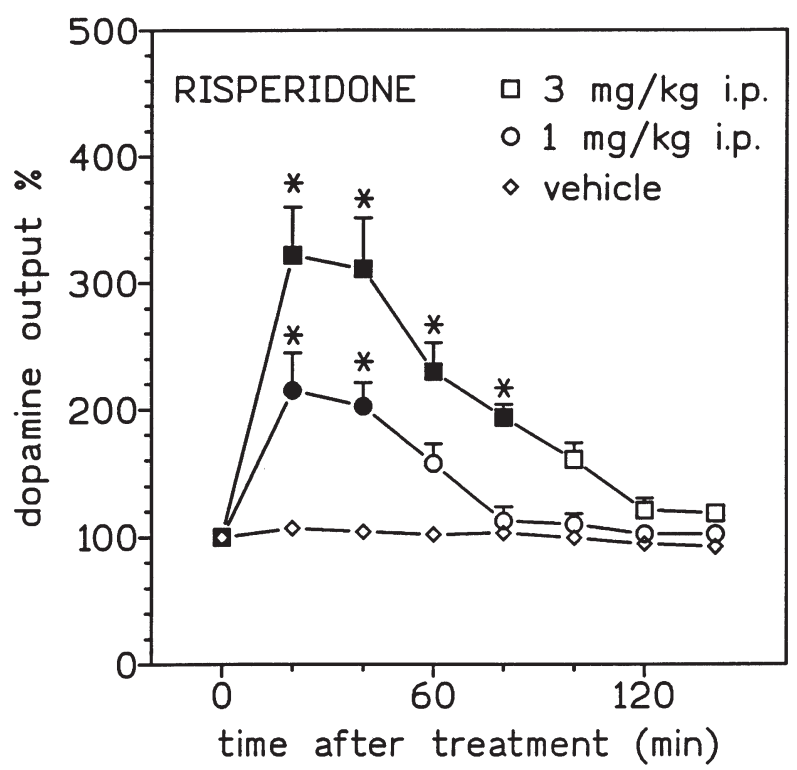

Figure 3. Effect of risperidone at 1 and $3 \mathrm{mg} / \mathrm{kg}$ IP on DA concentration in dialysate obtained by in vivo microdialysis from the bed nucleus of stria terminalis (BNST). Each point is the mean \pm SEM of at least four determinations. Filled symbols: $p<.05$ from basal values concentration; ${ }^{*} p<.05$ from the correspondent time point of vehicle group.

a significant effect were the $5-\mathrm{HT}_{2 \mathrm{~A}}$ antagonist ritanserin (Leysen et al. 1985), (0.5 and $1.5 \mathrm{mg} / \mathrm{kg} \mathrm{IP),} \mathrm{(Figure} \mathrm{10)}$ and the adrenergic $\alpha_{1}$ antagonist prazosin (Baldessarini et al. 1992), (0.91 and $2.73 \mathrm{mg} / \mathrm{kg} \mathrm{IP)}$, (Fig. 11).

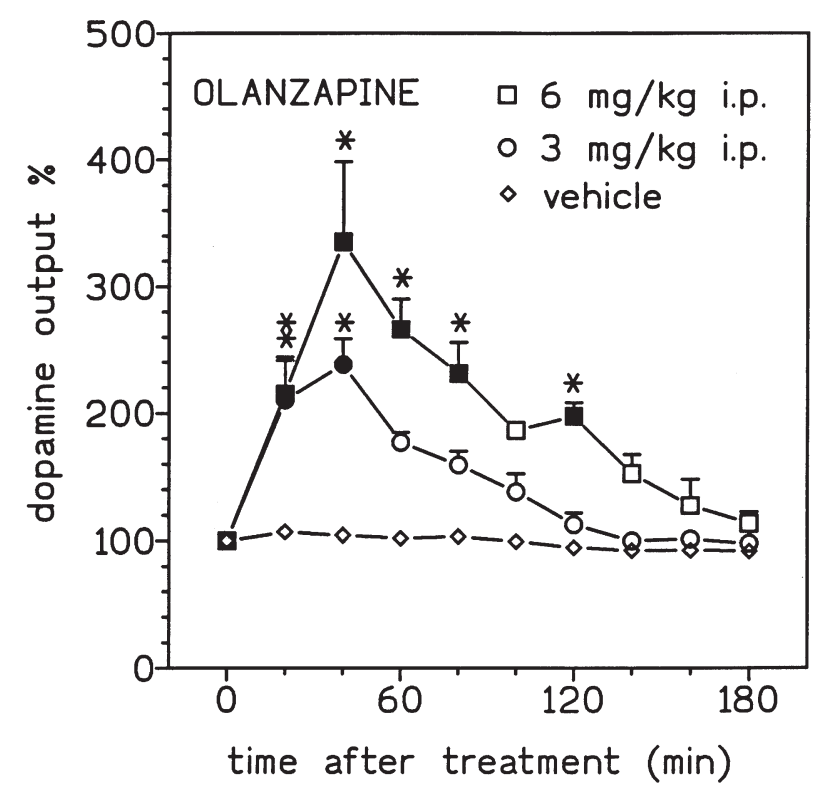

Figure 4. Effect of olanzapine at 3 and $6 \mathrm{mg} / \mathrm{kg}$ IP on DA concentration in dialysate obtained by in vivo microdialysis from the bed nucleus of stria terminalis (BNST). Each point is the mean \pm SEM of at least four determinations. Filled symbols: $p<.05$ from basal values concentration; ${ }^{*} p<.05$ from the correspondent time point of vehicle group. 


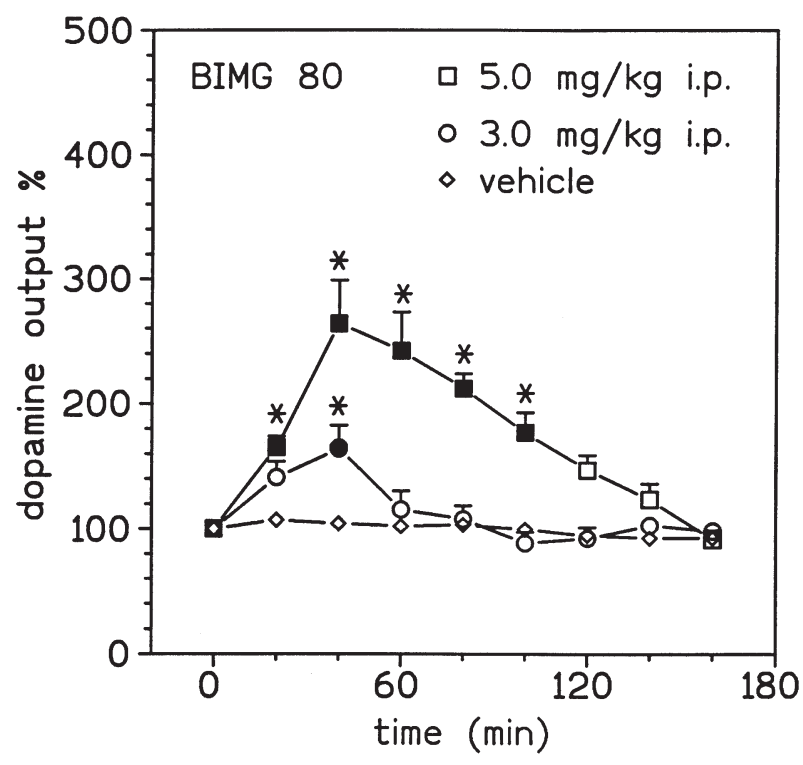

Figure 5. Effect of BIMG 803 and $5 \mathrm{mg} / \mathrm{kg}$ IP on DA concentration in dialysate obtained by in vivo microdialysis from the bed nucleus of stria terminalis (BNST). Each point is the mean \pm SEM of at least four determinations. Filled symbols: $p<.05$ from basal values concentration; ${ }^{*} p<.05$ from the correspondent time point of vehicle group.

\section{DISCUSSION}

The present study shows that clozapine and other putative atypical neuroleptics dose-dependently increase extracellular DA in the BNST; whereas, haloperidol and

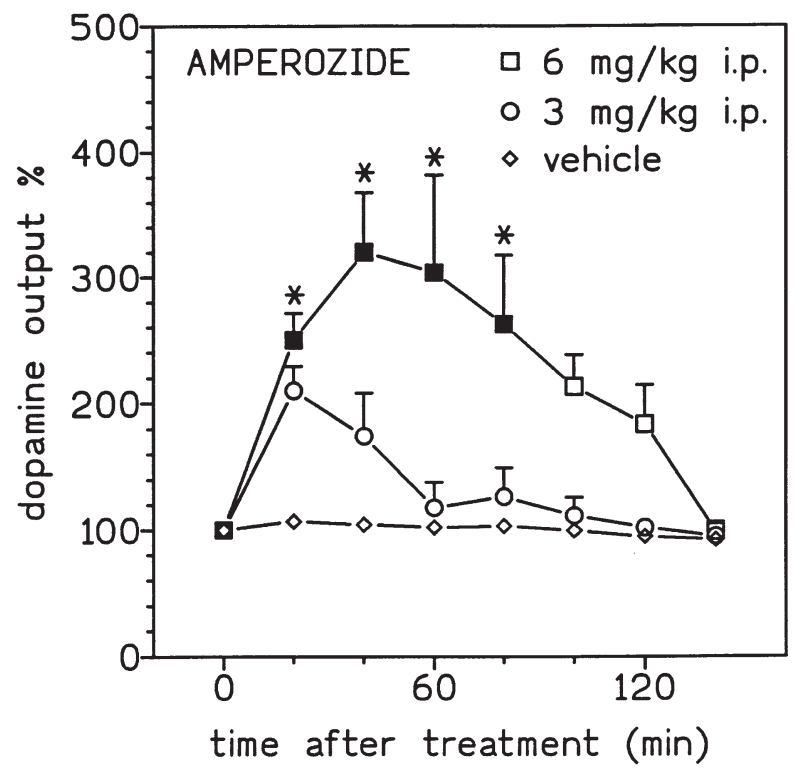

Figure 6. Effect of amperozide 6 and $3 \mathrm{mg} / \mathrm{kg}$ IP on DA concentration in dialysate obtained by in vivo microdialysis from the bed nucleus of stria terminalis (BNST). Each point is the mean \pm SEM of at least four determinations. Filled symbols: $p<.05$ from basal values concentration; ${ }^{*} p<.05$ from the correspondent time point of vehicle group.

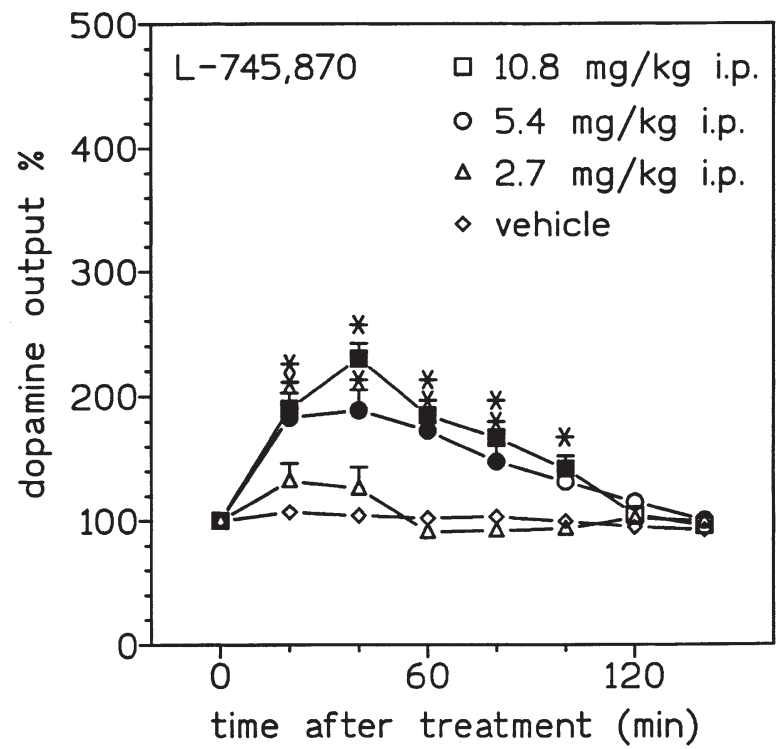

Figure 7. Effect of L-745,870 at 2.7, 5.4, and $10.8 \mathrm{mg} / \mathrm{kg}$ IP on DA concentration in dialysate obtained by in vivo microdialysis from the bed nucleus of stria terminalis (BNST). Each point is the mean \pm SEM of at least four determinations. Filled symbols: $p<.05$ from basal values concentration; ${ }^{*} p<.05$ from the correspondent time point of vehicle group.

raclopride are ineffective, even at doses known to be fully effective in a variety of pharmacological tests (i.e., catalepsy, stimulation of DA release in the striatum, blockade of motor-stimulation by DA-receptor agonists) (Arnt and Skarsfeldt 1998).

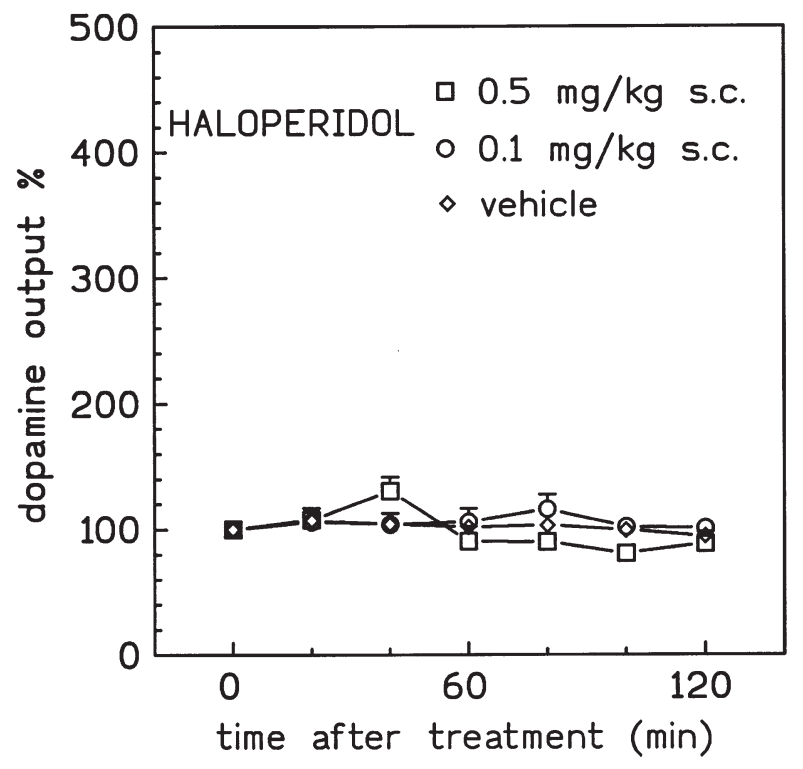

Figure 8. Effect of haloperidol at 0.1 and $0.5 \mathrm{mg} / \mathrm{kg} \mathrm{SC}$ on DA concentration in dialysate obtained by in vivo microdialysis from the bed nucleus of stria terminalis (BNST). Each point is the mean \pm SEM of at least four determinations. 


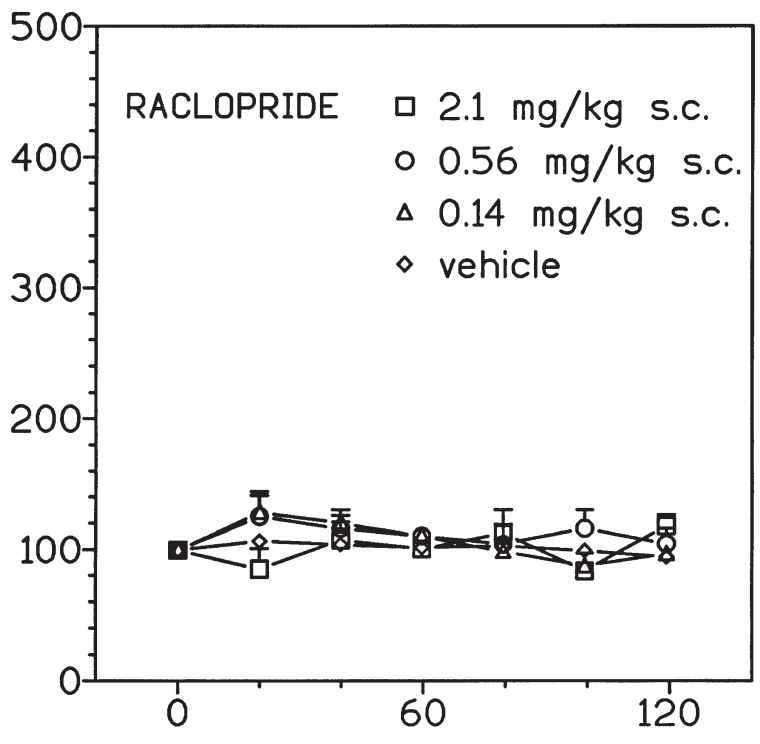

Figure 9. Effect of raclopride at the dose of $0.14,0.56$, and $2.1 \mathrm{mg} / \mathrm{kg}$ SC on DA concentration in dialysate obtained by in vivo microdialysis from the bed nucleus of stria terminalis (BNST). Each point is the mean \pm SEM of at least four determinations.

Clozapine increased DA in dialysates from BNST at doses lower than those effective in raising DA concentration in dialysate from the prefrontal cortex (Nomikos et al. 1994; Volontè et al. 1997); risperidone raised DA in the BNST only at doses about twofold higher than those active in increasing dialysate DA in the prefrontal cor-

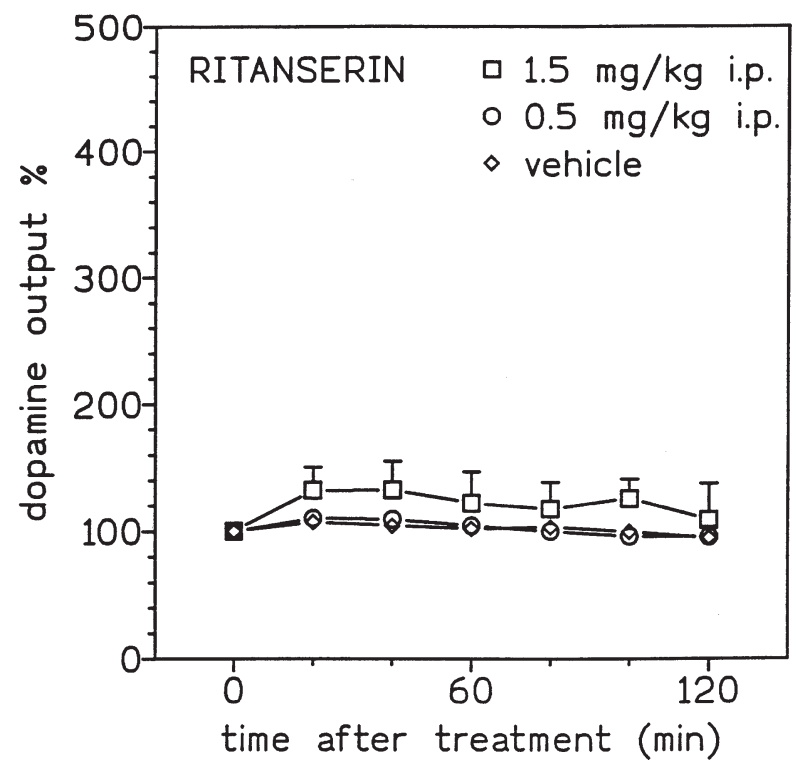

Figure 10. Effect of ritanserin at the dose of 0.5 , and 1.5 $\mathrm{mg} / \mathrm{kg}$ IP on DA concentration in dialysate obtained by in vivo microdialysis from the bed nucleus of stria terminalis (BNST). Each point is the mean \pm SEM of at least four determinations. tex (Hertel et al. 1996; Volontè et al. 1997). Olanzapine, BIMG 80, and amperozide, instead, were equipotent in increasing DA in dialysates from the BNST and from prefrontal cortex (Nomikos et al. 1994, Volontè et al. 1997, Xi-Ming et al. 1998). On the other hand, haloperidol and raclopride, which are poorly active in the prefrontal cortex (Volontè et al. 1997) are ineffective in raising DA concentration in dialysates from the BNST. These observations suggest that the mechanism by which atypical neuroleptics stimulate DA transmission in the BNST, although differing from that effective in the dorsal striatum, might be similar to that effective in the prefrontal cortex.

The mechanism by which clozapine and other atypical neuroleptics increase DA in BNST dialysates is unlikely to be attributable solely to blockade of $D_{2}$ receptors. If this were the case, haloperidol and raclopride would have been fully effective in this respect. The effectiveness of amperozide on DA in the BNST and its moderate to low affinity for $\mathrm{D}_{2}$-like receptors (Meltzer et al. 1989) confirms that the ability of increasing DA in the BNST is not directly related to an action on $\mathrm{D}_{2}$-like receptors. It is possible, however, that the increase of DA in the BNST is the result of a combined action at $\mathrm{D}_{2}$ receptors and at non-DA receptors. Clozapine and other atypical neuroleptics (risperidone, olanzapine, BIMG 80) have an affinity for $5-\mathrm{HT}_{2 \mathrm{~A}}$ and $\alpha_{1}$ receptors higher or in the same range of that for the $\mathrm{D}_{2}$ receptors (Arnt and Skarsfeldt 1998; Leysen et al. 1993, 1994; Malmberg et al. 1993); in contrast, haloperidol and raclopride have a comparatively low or no activity at

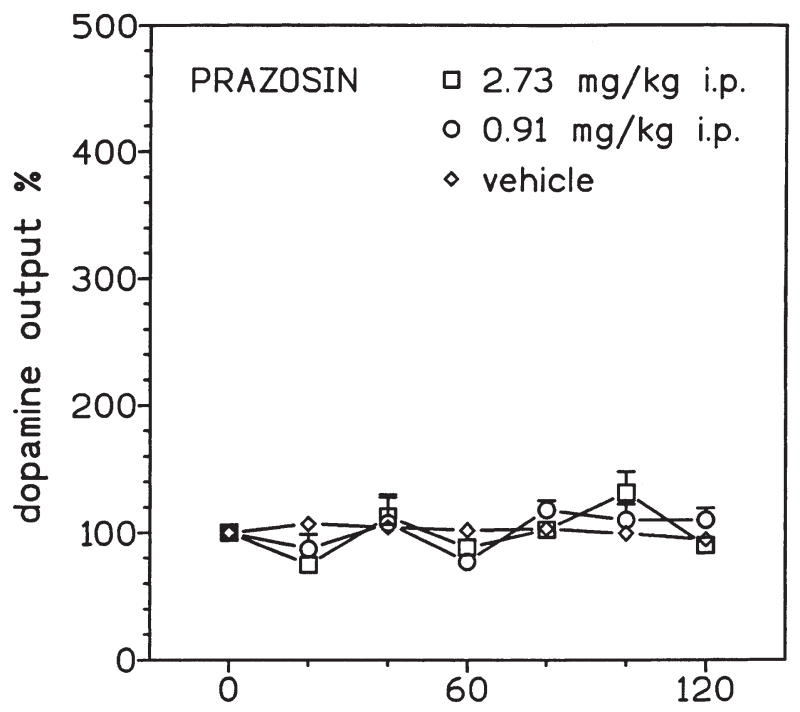

Figure 11. Effect of prazosin at the dose of 0.91 and 2.73 $\mathrm{mg} / \mathrm{kg}$ IP on DA concentration in dialysate obtained by in vivo microdialysis from the bed nucleus of stria terminalis (BNST). Each point is the mean \pm SEM of at least four determinations. 
5- $\mathrm{HT}_{2 \mathrm{~A}}$ or $\alpha_{1}$ receptors (Arnt and Skarsfeldt 1998). A role of muscarinic receptors should be excluded on the basis of the low affinity of risperidone, amperozide, and BIMG- 80 for these receptors. Using a similar argument, we can exclude a role of $\alpha_{2}$ receptors, given the low affinity of olanzapine, amperozide, and BIMG-80 for these receptors (Arnt and Skarsfeldt 1998; Volontè et al. 1997; Nomikos et al. 1994). On the other hand, the observation that ritanserin, a 5- $\mathrm{HT}_{2 \mathrm{~A} / \mathrm{C}}$ antagonist, and prazosin, an $\alpha_{1}$ antagonist, given at pharmacologically active doses, fail to increase DA in the BNST indicates that is not the blockade of any of the above receptors by itself, which determines the property of increasing DA in the BNST. In relation to this, the limited efficacy of the specific $\mathrm{D}_{4}$-antagonist $\mathrm{L}-745,870$ is also notable. L-745,870 increased dialysate from BNST by $100 \%$, an effect that reached a plateau at the dose of $5.4 \mathrm{mg} / \mathrm{kg}$, a rather high dose if we consider that the affinity of L-745,870 for the cloned human $\mathrm{D}_{4}$ receptors is 5 to 20- fold higher than that of haloperidol (Bristow et al. 1997).

At the moment, we tentatively propose that the property of increasing dialysate DA in the BNST, similar to that of increasing DA in the prefrontal cortex (Andersson et al. 1995), is the result of a combined blockade of $\mathrm{D}_{2}$-like (including $\mathrm{D}_{4}$ ) $5-\mathrm{HT}_{2 \mathrm{~A}}$ and eventually $\alpha_{1}$ receptors. This possibility is, in turn, consistent with the presence in the BNST, in addition to DA, of a dense noradrenergic (Tohyama and Taketsuji 1998) and a significant serotonergic innervation (Tork 1991). This hypothesis is currently being tested in our laboratory.

Whatever the mechanism of DA stimulant effect of atypical neuroleptics in the BNST, our results raise the possibility that the DA stimulant effect of atypical neuroleptics play a role in the peculiar therapeutic profile of atypical neuroleptics. In fact, the BNST as part of the extended amygdala plays a critical role in the integration between sensory and biological properties of stimuli and in learning and expression of emotions (Alheid and Heimer 1996, 1993). Thus, blockade of DA transmission in the BNST or in other DA terminal areas, eventually combined with blockade of non-DA receptors $\left(5-\mathrm{HT}_{2 \mathrm{~A}}\right.$ and $\left.\alpha_{1}\right)$, might result in a feedback increase of DA release in the BNST onto a DA receptor subtype not blocked by the atypical neuroleptic. Therefore, an increase of DA transmission onto specific DA receptor subtypes might be instrumental for the antipsychotic effects of atypical neuroleptics. Similar considerations have been applied to the increase of DA release in the prefrontal cortex, which apparently behaves in a manner similar to the BNST in response to atypical neuroleptics (Andersson et al. 1995; Hertel et al. 1996; Volontè et al. 1997). It is notable, however, that typical neuroleptics increase, although to a lesser extent, extracellular DA in the prefrontal cortex whereas, they are without effect in the BNST.
In conclusion, although the mechanism of the DA stimulant effect in the BNST observed in this study is unclear, the observation that this property is shared by drugs with a clozapine-like receptor affinity pattern suggests that such a property might be predictive of an atypical neuroleptic profile and that an action on DA transmission in the BNST may play a role in the peculiar therapeutic properties of atypical neuroleptics.

\section{REFERENCES}

Alheid GF, Heimer L (1996): Theories of basal forebrain organization and the "emotional motor system." Prog Brain Res 107:461-484

Alheid GF, Heimer L (1988): New perspective in basal forebrain organization of special relevance for neuropsychiatric disorders: The striatopallidal, amygdaloid, and corticopetal components of substantia innominata. Neuroscience 27:1-39

Andersson JL, Nomikos GG, Marcus M, Hertel P, Mathé JM, Svensson TH (1995): Ritanserin potentiates the stimulatory effects of raclopride on neuronal activity and dopamine release selectively in the mesolimbic dopaminergic system. Naunyn Schmiedebergs's Arch Pharmacol 352:374-385

Arnt J, Skarsfeldt T (1998): Do novel antipsychotics have similar pharmacological characteristics? A review of the evidence. Neuropsychopharmacology 18:63-101

Baldessarini RJ, Huston-Lyson D, Campbell A, Marsh E, Cohen BM (1992): Do central antiadrenergic actions contribute to the atypical properties of clozapine? Br J Psychiat 160:12-16

Beasley CM, Tollefson G, Tran P, Satterlee W, Sanger T, Hamilton $S$ (1996): Olanzapine versus placebo and haloperidol: Acute phase results of the North American double-blind olanzapine trial. Neuropsychopharmacology 14:87-96

Bristow JL, Kramer MS, Kulagoswski J, Patel S, Ragan IC, Seabrok GR (1997): Schizophrenia and L-745,870, a novel dopamine D4 receptor antagonist. Trends Pharmacol Sci 18:186-188

Brunello N, Masotto C, Steardo L, Markstein R, Racagni G (1995): New insights into the biology of schizophrenia through the mechanism of action of clozapine. Neuropsychopharmacology 13:177-212

Cohen BM, Lipinski JF (1986): In vivo potencies of antipsychotic drugs in blocking alpha 1 noradrenergic and dopamine $\mathrm{D}_{2}$ receptors: Implications for drug mechanisms of action. Life Sci 39:2571-2580

Coward DM (1992): General pharmacology of clozapine. Br J Psychiat 160:5-11

Deutch AY, Duman RS (1996): The effects of antipsychotic drugs on fos protein expression in the prefrontal cortex-Cellular localization and pharmacological characterization. Neuroscience 70:377-389

Hall H, Kohler C, Gawell L, Farde L, Sedvall G (1988): Raclopride, a new selective ligand for the dopamine-D2 receptors. Prog Neuropsychopharmacol Biol Psychiat 12:559-568

Haskins JT, Muth EA, Andree TH (1987): Biochemical and electrophysiological studies on the psychotropic compound, amperozide. Brain Res Bull 19:465-471 
Heimer L, Alheid GF, Zahm DS (1993): Basal forebrain organization: An anatomical framework for motor aspects of drive and motivation. In: Kalivas PW, Barnes CD (eds), The Mesolimbic Motor Circuit and its Role in Neuropsychiatric disorders. Boca Raton, CRC Press

Hertel P, Nomikos GG, Iurlo M, Svensson TH (1996): Risperidone: Regional effects in vivo on release and metabolism of dopamine and serotonin in the rat brain. Psychopharmacology 124:74-86

Imperato A, Di Chiara G (1985): Dopamine release and metabolism in awake rats after systemic neuroleptics as studied by trans-striatal dialysis. J Neurosci 5: 297-306

Imperato A, Angelucci L (1989): The effects of clozapine and fluperlapine on the in vivo release and metabolism of dopamine in the striatum and in the prefrontal cortex of freely moving rats. Psychopharmacol Bull 25:383-389

Leysen JE, Gommeren W, Van Gompel P, Wynants J, Janssen PF, Laduron PM (1985): Receptor-binding properties in vitro and in vivo of ritanserin: A very potent and long-acting serotonin-S2 antagonist. Mol Pharmacol 27:600-611

Leysen JE, Gommeren W, Mertens J, Luyten WHML, Pauwels PJ, Ewert M, Seeburg P (1993): Comparison of in vitro binding properties of a series of dopamine antagonists and agonists for cloned human $D_{2 S} D_{2} 1$ receptors and for $\mathrm{D}_{2}$ receptors in rat striata and mesolimbic tissues using [125]-2'-iodospiperone. Psychopharmacology 110:27-36

Leysen JE, Janssen PM, Megens AA, Schotte A (1994): Risperidone: A novel antipsychotic with balanced serotonin-dopamine antagonism, receptor occupancy profile, and pharmacological activity. J Clin Psychiat 55:5-12

Malmberg Å, Jackson DM, Eriksson A, Mohell N (1993): Unique binding characteristics of antipsychotic agents interacting with human dopamine D2A, D2B, and D3 receptors. Mol Pharmacol 43:749-754

Meltzer HY, Matsubara S, Lee JC (1989): Classification of typical and atypical antipsychotic drugs on the basis of dopamine $\mathrm{D}_{1}, \mathrm{D}_{2}$ and serotonin $2 \mathrm{pK}$ values. J Pharmacol Exper Ther 251:238-246

Moghaddam B, Bunney BS (1990): Acute effects of typical and atypical antipsychotic drugs on the release of dopamine from prefrontal cortex, nucleus accumbens, and striatum of the rat: An in vivo microdialysis study. Neurochemistry 54:1755-1760

Nomikos GG, Iurlo M, Andersson JL, Kimura K, Svensson TH (1994): Systemic administration of amperozide, a new atypical antipsychotic drug, preferentially increases dopamine release in the rat medial prefrontal cortex. Psychopharmacology 115:147-156

Paxinos G, Watson C (1982): The Rat Brain Stereotaxic Coordinates. New York, Academic Press

Robertson GS, Fibiger HC (1992): Neuroleptics increase c-fos expression in the forebrain: Contrasting effects of haloperidol and clozapine. Neuroscience 46:315-328

Tohyama M, Taketsuji K (1998): Atlas of Neuroactive Substances and Their Receptor in the Rat. New York, Oxford University Press

Tork I (1991): Anatomy of the serotonergic system. Ann NY Acad Sci 600:9-34

Van Tol HHM, Bunzow JR, Guan HC, Sunahara RK, Seeman P, Niznik HB, Civelli O (1991): Cloning of the gene for a human dopamine $\mathrm{D}_{4}$ receptor with high affinity for the antipsychotic clozapine. Nature 350:610-614

Volontè M, Monferini E, Cerutti M, Fodritto F, Borsini F (1997): BIMG 80, a novel potential antipsychotic drug: evidence for multireceptor actions and preferential release of dopamine in prefrontal cortex. J Neurochem 69:182-190

Xi-Ming L, Perry KW, Wong DT, Bymaster FB (1998): Olanzapine increases in vivo dopamine and norepinephrine release in rat prefrontal cortex, nucleus accumbens and striatum. Psychopharmacology 136:153-161 